\title{
KÁRMÁN TÓDOR - EGY MAGYAR FELTALÁLÓ MUNKÁSSÁGA
}

\section{TÓDOR KÁRMÁN - WORK OF A HUNGARIAN INVENTOR}

\author{
Gáti József,, ${ }^{1}$ Osváth Rebeka, ${ }^{2}$ Kuti János ${ }^{3}$ \\ Óbudai Egyetem, Budapest, Magyarország \\ 1 gati@uni-obuda \\ ${ }^{2}$ rebeka.osvath@gmail.com \\ ${ }^{3}$ kuti.janos@rh.uni-obuda
}

\begin{abstract}
Unworthily we forget many great Hungarian engineers, who could be great role models for today's young engineers. In some respects, Tódor Kármán belongs to these forgotten engineers. That's why I present in my dissertation the life and work of Tódor Kármán. I deal specifically with his contemporary education system, because this was also due to his scientific work. During my scientific work, I reveal the most important works, studies of the great scientist, I am focusing on his space exploration activities before his age. In this respect, I will also talk about one of his followers, Dr. Antal Bejczy.
\end{abstract}

Keywords: history of technology, biography, hungarian inventor.

\section{Összefoglalás}

Méltatlanul felejtünk el több nagy magyar mérnököt, akik a mai fiatal mérnököknek is remek példaképek lehetnének. Bizonyos tekintetben ezen elfeledett mérnökök közé tartozik Kármán Tódor is. Éppen ezért kutatásunkban bemutatjuk Kármán Tódor életét és munkáságát. Külön foglalkozom az Ő korabeli oktatási rendszerrel, hiszen ennek is köszönhető volt a tudományos munkásága. Munkám során feltárom a kiváló Tudós legfontosabb munkáit, találmányait, kiemelten foglalkozom a korát megelőző űrkutatási tevékenységével. E tekintetben kitérek az ürkutatásban az egyik követőjére is Dr. Bejczy Antalra.

Kulcsszavak: technikatörténet, életrajz, magyar feltaláló.

\section{Kármán Tódor családja}

Kármán Tódor 1881. május 11-én született, Budapesten, a Kármán család harmadik gyermekeként.

Édesanyja Helen Kohn (Magyar Országos Pedagógiai Könyvtár anyagai szerint Kohn Ilka) családfája visszavezethető a prágai császári udvar nagy matematikusáig, az első mechanikus robot, a Gólem megalkotójáig.

Édesapja, Kármán Mór 1843-ban született egy szegedi zsidó családban. Lőw Lipót rabbi ösztönözte tanulásra és szorgalmazta, hogy belőle is rabbi legyen. Mór fontosabbnak tartotta az iskolát, mint a vallást, ezért a bécsi egyetemre ment, hogy filozófiát hallgathasson. Diplomája megszerzése után visszatért Magyarországra, doktori címét itt szerezte meg. 1869-ben az oktatásügyi miniszter, Eötvös József báró tanácsára Lipcsébe utazott, hogy tanulmányozza a német oktatási rendszert.

Kármán Mór kötelező, hároméves tantervet javasolt német és francia példára, célja ezzel nem csak az egységesítés volt, hanem egyben az is, hogy az oktatás szervezése egyházi kézből állami irányítás alá kerüljön. Eközben Eötvös báró elhunyt, de utódjára, Pauler Tódorra is nagy hatással voltak az újító elképzelések, így később Kármán Mór a Nemzeti Oktatásügyi Tanács főtitkára lett, a tanács pedig folytatta az átszervezés kidolgozását. Sikerei hatására állást kapott a császári udvarban, Ferenc József 


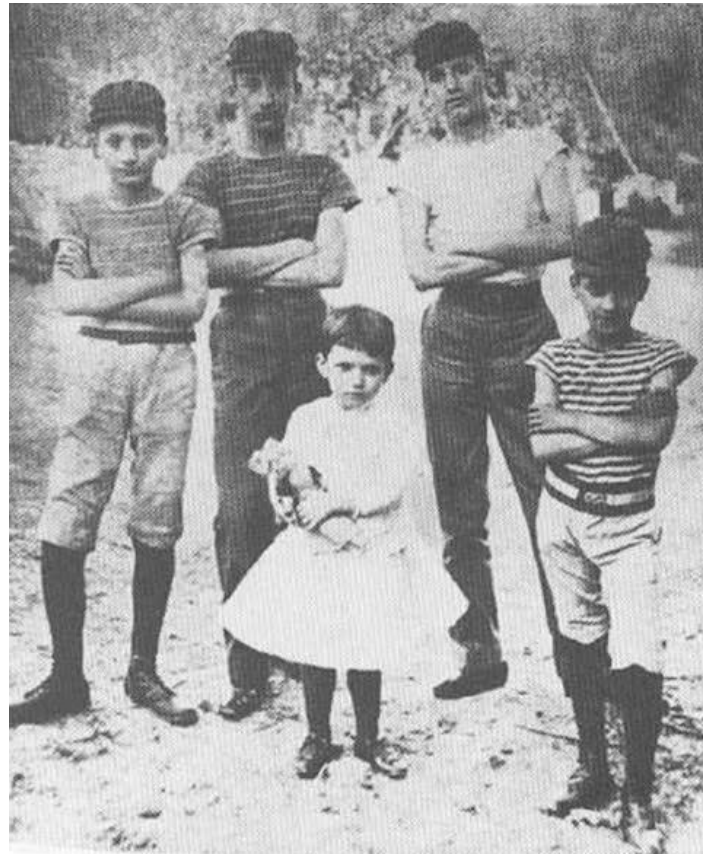

1. ábra. A Kármán gyerekek, Tódor a bal oldalon látható

unokaöcsének, Albrecht főhercegnek az oktatását kellett megterveznie, ekkor kapott munkásságáért elismerésként nemesi címet a császártól. A nemesi címhez saját földbirtokra volt szükség, a család tulajdonában pedig egyetlen kis szőlőskert állt, Budapesttől nem messze, így lett a család nemesi előneve végül “von Szőlőskislak”. Kármán Tódor mellé magántanítót fogadtak édesapja egyik volt tanítványa, Dr. Málnai személyében. Irodalmat, történelmet és földrajzot tanult. Gyermekkorában nagyon tehetséges fejszámolónak bizonyult, különböző családi összejövetelekkor gyakran kérték meg, hogy adjon össze vagy vonjon ki egymásból nagy számokat. Ezeket mindig, hiba nélkül el is végezte. Hiába mutatott érdeklődést a matematika iránt, édesapja kérésére tizenéves koráig tartózkodott tőle, mivel apja nem akarta, hogy csodabogár legyen belőle. Kármán Mór elvei szerint a családban a gyermekeknek tanítva kellett tanulniuk, így legidősebb bátyja Elemér, a sorban utána következő Ferit tanította, Feri pedig később Tódor tanítója lett. Mikor öccse, Miklós betöltötte 5. életévét, Tódor őt kezdte el tanítani. Pipő, a húguk volt a legkisebb testvér, őt már mindenki tanítgatta.

Tódort 9 évesen beíratták a Trefort utcában lévő gyakorlógimnáziumba. A ”Minta” gimnáziumot édesapja alapította, az ő oktatási elveire épülve müködött.
A hatékony oktatás titka Kármán Mór szerint az volt, hogy a diákok úgy tanulják a tantárgyakat, hogy közben lássák a hasznosságukat, hogy érezzék a tudományok hétköznapi élettel való kapcsolatát.

Matematika órán, statisztika témakör kapcsán például Magyarország gabonatermésének adatait tanulmányozták, ehhez diagrammokat és táblázatokat készítettek.

Szabályokat sosem tanultak meg szó szerint, ehelyett levezetéssel próbálták megérteni őket. A logika elsajátítására nevelték a gyermekeket.

Magyarországon a Mintagimnázium volt az első iskola, ahol egyetemi hallgatók is oktattak. A középiskolás diákok minden évben versenybe szálltak egymással az Eötvös-díj elnyeréséért. Ezzel a díjjal olyan diákokat jutalmaztak, akik matematikából, természettudományokból jeleskedtek. A díj nem csak a kitüntetett diák számára, hanem a felkészítő tanárának is hatalmas elismerés volt. A versenyen Kármán Tódor is indult és végül meg is nyerte azt. Tudományos életútja során meghatározó volt a Mintában szerzett tudás és magabiztosság..

\section{Egyetemi évek}

1889-ben Kármán Tódor beiratkozott a József Nádor Mủegyetemre. A matematika előadások közel álltak a szívéhez, de a matematikai foglalkozásokon belül az ábrázoló geometriát szerette a legjobban. Irodalmat és történelmet is hallgatott néhány féléven keresztül, időnként kedvet kapott még a versíráshoz is. A közgazdaságtant viszont elhanyagolta. Az egyetemen eltöltött évek során fontos személyiség volt Bánki Donát professzor. Nem csak ő ápolt jó kapcsolatot kedvelt tanárával, de egyben édesapja jó barátja is volt. Első műszaki közleménye Bánki segítségével látott napvilágot. Egy, a motorokban előforduló problémára kereste a megoldást. A konkrét kérdés az volt, hogy "Miért jönnek néha nagy zajt okozva rezgésbe a szelepek?” Bánkinak annyira tetszett a munkája, hogy úgy döntött, egy általa írt könyvben, - amiben különböző műszaki problémákkal kapcsolatos tanulmányokat foglalt össze - megjelenteti Kármán Tódor kutatását is.

1902-ben "mit Ausreichen”, tehát kitüntetéssel végezte el az egyetemet. Ezután behívták az osztrák-magyar hadseregbe, ahol a tüzérségnél szolgált. Ekkor még nem tudhatta, hogy pályafutása során milyen fontos szerepet fog betölteni a haditechnika. Szolgálati éve után visszatért a Múegyetmre, hogy Bánki professzor tanársegédje lehessen. 1905-ben érdeklődni kezdett a rugalmas egyensúly instabilitásának jelensége iránt. Elő- 
ször Leonhard Euler foglalkozott a problémával, de az ő elmélete csak a teljesen rugalmas oszlopokra volt érvényes. A témával kapcsolatos első eredményeit a Mérnök És Építész Egylet Közlönyében publikálta. Szakmai körökben közleményének nem volt nagy visszhangja, viszont édesapját annál jobban elvarázsolta. Kármán Mór arra biztatta fiát, hogy tanulmányait külföldön folytassa.

Hosszas mérlegelés után Németországra esett a választás.: Kármán Tódor kétéves Göttingenbe szóló ösztöndíjat kapott. Tódor úgy emlékszik vissza a göttingeni egyetemre, mint a világ vezető matematikai központjára, ahol többek között Planck, Gauss és Hilbert is tevékenykedtek. Az egyetem alkalmazott fizika osztályát vezető professzor, Ludwig Prandtl kezdett el érdeklődni a kihajlási elmélete iránt. Prandtl ígéretet tett, hogy beszerzi a hidraulikus sajtót, amire szüksége lett volna kísérletei elvégzéséhez, de Tódor hiába várakozott, nem történtek fejlemények az ügyben. Elkeseredésében döntött, elhagyja Göttingent, mivel azt érezte, hiába hallgatja az előadásokat, a tanulmányával kapcsolatban mégsem jut egyről a kettőre. 1907-ben beiratkozott a charlottenburgi egyetemre, de gyorsan rájött, hogy az intézmény hiába fogadta őt szívesen, nem volt meg a megfelelő felszereltségük a kísérleteihez, ezért a rövid kitérő után visszairatkozott Göttingenbe.A hidraulikus sajtót Göttingenben építették fel, Kármán Tódor itt végezte el kísérleteit. Végül 1908-ban elkészült doktori munkájával, melyet 1909-ben publikált. 1908 telén véget ért a göttingeni ösztöndíj. A következő állomás Franciaország volt, méghozzá a párizsi Sorbonne egyetem, ahol többek között Marie Curie előadásait is hallgatta. Franciaországban kezdték el érdekelni a repülőgépek, pontosabban először a repülőgépek motorjai büvölték el, később azon is gondolkozott, hogy hogyan lehetne biztonságosabbá tenni a repülést. A motorok terén biztos volt abban, hogy a repülőgépek fejlődésének titka a motorok tömegének csökkentésében rejlik, több repülőgéptervezővel is felvette a kapcsolatot ebben az ügyben. Kármán Tódor nem maradt sokáig Párizsban. Prandtl egy olyan szélcsatornát akart építeni, amelyben tesztelni tudták a léghajó modelljét. Kármán Tódortól azt kérték, hogy ebben segédkezzen. Az aerodinamikai tesztek támogatása mellett felkérték, hogy magántanárként tartson mechanika előadásokat az egyetemen.

\section{Repüléstudomány}

Kármán egyik utazása során, Bolognában, egy múzeumban felfigyelt egy festményre. A kép Szent Kristófot ábrázolta, amint átkel a vízen, Jézussal a vállán. Észrevette, hogy a festményen a szent lábai mögött ide-oda örvénylik a víz. Sokat gondolkozott azon, hogy mi miatt keletkeztek az örvények.

Prandtl ezidőtájt az állandósult sebességű vízáramba helyezett körhenger felületének különböző pontjaiban mérhető nyomás nagyságát tanulmányozta. Egyik doktoranduszára bízta rá az ezzel kapcsolatos kísérletek elvégzését. A kísérletek nem hoztak megfelelő eredményeket. Kármán elhatározta, hogy utánajár a dolgoknak.

Azt feltételezte, hogy a henger körül keletkező örvények egymást váltva válnak le a henger felső és alsó részéről. Miután ezt a mozgást vizsgálta, rájött, hogy csak abban az esetben lehet stabil ez a helyzet, ha az örvények nem kettesével, egyszerre, hanem egymáshoz képest eltolva jelennek meg. Ezzel az elmélettel vált nemzetközileg elismert kutatóvá a repüléstudomány terén.

1912-ben már négy éve tevékenykedett magántanárként Göttingenben, mikor megpályázta a Selmecbányán lévő Mária Terézia által alapított bányászati akadémia alkalmazott matematika tanszékének vezetését. Kármán felajánlotta, hogy kér egy év szabadságot, hogy befejezhesse a munkáját Göttingenben.

1913-ban az aacheni műszaki főiskola repüléstudományi tanszékéről kapott ajánlatot, ezért lemondott a selmecbányai állásról. Az intézmény a metallurgiai és bányászati mérnöki képzéseiről volt híres. Az, hogy repüléstudományt is oktattak, Hugo Junkers professzornak volt köszönhető, aki az egyetemet elhagyva, később repülőgépgyártással foglalkozott, így vált Kármán egyik fontos ügyfelévé. Junkers távozása előtt azt javasolta, hogy hozzanak létre repüléstudományi tanszéket. Bár létrejött az új tanszék, de a repüléstudomány mellett a mechanika is helyet kapott. Kármán miután elfoglalta helyét a tanszéken, első dolga az volt, hogy fejlessze a meglévő szélcsatornát. Göttingeni mintára szerette volna átalakítani, mivel a német egyetemen már kitapasztalták, hogy jobb eredményeket tudnak elérni, ha nem engedik ki a vizsgálatokhoz használt levegőt és szívnak be a laborba friss levegőt a szabadból, hanem a bent lévő levegőt keringetik. Így nem befolyásolja a kísérleteket a levegő összetétele és a szennyező anyagok. 1914-ben készült el a szélcsatorna. 
Egy napon Hugo Junkers meglátogatta Kármán Tódort, olyan repülőgépet szeretett volna gyártani, ami merőben eltért az eddigi vászonborításos szerkezetektől. Célja az volt, hogy az egész repülőgép fémből készüljön. Azt kérte Kármántól, hogy dolgozzon ki egy olyan matematikai módszert, aminek segítségével megtalálhatja a legalkalmasabb szárnyformát. Kármán otthonosan érezte magát Aachenben, szoros kapcsolatokat épített ki kollégáival és diákjával is. Egy napon néhány német pilóta megkérte őt, hogy tanítson nekik repülés elméletet, cserébe megígérték, hogy megtanítják repülni. Kármán Tódor első repülése Kölnben történt egy Taube típusú repülőgéppel. Kármán szerint jó gép volt, egyetlen hibával, leszálláskor könnyedén előrebukott.

\section{A nagy háború}

1914-ben, egy őszi napon Kármánnak hivatalos leve érkezett, melyben parancsot kapott, hogy jelentkezzen szolgálatra a tüzérséghez. Azzal bizták meg, hogy határozza meg Budapest védelméhez szükséges tüzérség típusát, arra az esetre, ha az orosz katonák megtámadnák. Később a hadügyminiszter Bécsbe hívta, ahol tájékoztatást kapott a további tervekről. Bécstől nem messze, Fischamend városában épült egy hatalmas repülőtér, ide küldték Kármánt - ahol egy zeppelin hangárt akartak létrehozni, de Kármán javaslatára ehelyett kísérleti laboratóriumot építettek. Következő megbízása keretein belül ki kellett találnia, hogy hogyan lássa el olyan gépfegyverrel a repülőgépeket, amely el tud lőni a forgó légcsavar lapátjai között. Franciaországban, Roland Garrosnak volt erre egy módszere. Egy napon, miközben tesztelték a gépfegyvert, baleset történt, a légcsavar öszszetört a pilóta pedig német területre zuhant. A pilótát elfogták mielőtt megsemmisíthette volna a repülőgépet. A lefoglalt szerkezetet odaadták Anthony Fokker, holland származású mérnöknek, aki rájött a gépfegyver hibájára és kijavította azt. Kármán szerint a szinkronizált gépfegyvernek köszönhető a vadászgépek fejlődése. A közös munka során Kármán és Fokker barátságot kötöttek. 1917-ben Kármán helikopterkísérletekben vett részt. A cél az volt, hogy kiváltsák az eddig megfigyelésre használt léggömböket, azért, mert úgy gondolták, hogy a helikopter biztonságosabb lehetne. Zsuroveczzel és Asbóthtal közösen fejlesztették ki a "kötött helikoptert".

Azért volt, kötött, mert a stabilitás miatt három kötéllel volt a földhöz rögzítve. Két légcsavarja volt, amelyek egymással ellentétes irányba fo- rogtak. Leghíresebb modelljük tömege $200 \mathrm{~kg}$, amelyet 3 db 120 lóerős motorral működtetek. A budapesti Lipták-gyárral kötöttek szerződést, ők bonyolították le a helikopterek gyártását.

Kármánt arra kérték, alakítsa át helikopterét, hogy az alkalmas legyen utánpótlás szállítására, arra az esetre, ha Berlint megostromolnák és ellenséges katonák vennék körbe. Hiába magyarázta el a német vezetőknek, hogy a helikopter egyenlőre nem tud olyan ütemben fejlődni, hogy erre egyhamar képes legyen, mégis parancsot kapott, hogy találja meg a megoldást. 1919-ben visszautazott Aachenbe. A versailles-i békében leírtak alapján a motoros repülőgépek gyártása tiltott dolog volt akkoriban. Néhány diák repülés iránti érdeklődését azonban nem tudták elnyomni, megalapították az Aacheni Repüléstudományi Egyesület névre hallgató diákkört. Azzal a kéréssel fordultak Kármánhoz, hogy segítsen nekik vitorlázó repülőgépet építeni. A diákok körében gyorsan végig söpört a repülőgépépítési láz. 1920-ra elkészült az aacheni diákok repülője is, Schwarzer Teufel.. A következő repülőgépük a Blaue Maus (magyarul: Kék Egér) 1921-ben készült el. A gép 13 percet repült, ezzel megdöntötték az akkori világrekordot. Hugo Junkers felkérte Kármánt, hogy legyen a tanácsadója. 1924ben Kármán Tódor meghívást kapott a Boden-tó mellett elhelyezkedő Zeppelin Művekhez. A hajó 1924-ben készült el, ősszel hagyta el Németországot, 4 nap alatt, $7830 \mathrm{~km}$ megtétele után érte el célját, New Jerseyt.

\section{Az Egyesült Államok és Ázsia}

1926-ban Kármán Tódor táviratot kapott Dr. Robert Millikantól, a California Institute of Technology vezetőjétől, melyben arra kérte Kármánt, hogy utazzon el hozzá az Egyesült Államokba, azért, hogy segítsen egy aerodinamikai labor kialakításában. Ugyanekkor Japánból is érkezett egy felkérés Kármán számára, amelyben szintén arra kérték, hogy segédkezzen egy repüléstudományi laboratórium létrehozásában. Robert Andrews Millikan 1922-ben vette át a Cal Tech vezetését. Mire Kármán 1926-ban megérkezett, addigra két fiatal, Clark Millikan és Arthur Klein már dolgoztak a tervezett szélcsatornán. A cél egy Eiffel féle szélcsatorna létrehozása volt, de Kármán egy hatékonyabb tervet javasolt. 1926 őszére készültek el a labor terveivel. Kármán Tódor 1927-ben érkezett meg Jokohamába. Azt kérték Kármántól, hogy tervezzen egy szélcsatornát és tartson oktatást mérnökeiknek. 1928-ra fejezték be a szélcsa- 
torna építését. A Kavanisi Gépgyárban ebben az évben kezdték el gyártani a saját repülőgépeiket.

Németországban egyre nagyobb teret nyert a nacionalizmus. Hiába szerette Kármán Aacheni életét, elbizonytalanodott, így 1931 és 1932 között Németország és Pasadena között ingázott. Végül 1933-ban felszólították, hogy térjen vissza állásához, vagy mondjon le a pozíciójáról. Kármán végül a Cal Techet választotta.

1937-ben Frank Wattendorf, aki akkor a kínai Csing Hua Egyetem repüléstudományi karát vezette meghívta Kármánt Pekingbe. Ezzel egyidőben egy orosz mérnök szintén felkéréssel fordult Kármánhoz, hogy látogasson el Moszkvába. 1937 nyarán Kármán elindult Oroszországból és folytatta útját Mandzsúriába.

Kínában Wattendorf már várta Kármánt, a határtól együtt utaztak Pekingbe. A kínai repülőgépflotta főleg amerikai és olasz repülőgépekből állt, de ezeknek a gépeknek a szervízelése gyakran okozott fejtörést a kínai technikusoknak. Repülőgépgyárat már Kármán érkezése előtt létesítettek, a következő célkitűzés a kutatórészleg volt. Wattendorf tanácsára belekezdtek egy 5-6 méter átmérőjű és 70-100 méter hosszú szélcsatorna építésébe, amelyet költséghatékonyság céljából a kínai hallgatók terveztek és építettek.

\section{Olaszország: Az 5. Volta Kongresszus}

Ez volt az első fontos esemény a szuperszonikus repülés lehetőségét illetően. A világ nagyobb nemzetei mind megjelentek a kongresszuson, többek között a Szovjetunió is. Kármánt 1908-ban kezdték el érdekelni a szuperszonikus jelenségek, ekkor cikket is írt a "hangnál nagyobb sebességü légáramlásban keletkező lökésekről”. 1931-ben, Pasadenaban kezdte komolyabban vizsgálni a “lövedék körüli szuperszonikus légáramlást”. Úgy tekintett a lövedékekre, mint piciny léghajókra. Kármán egyik doktorandusza, Norton Moore közremüködésével 1932-ben közétett egy tanulmányt szuperszonikus aerodinamika témában. 1939-ben az Army Air Corps vezetője, Henry Arnold tanácsért fordult Kármán Tódorhoz, kérdése az volt, hogy hogyan tudnának fejlődést elérni a repülésben. Kármán azt javasolta, hogy fektessen be egy szuperszonikus szélcsatornába. Arnold megfogadta a tanácsot, Kármán és Wattendorf belekezdtek a szélcsatorna megtervezésébe. A nagysebességü szélcsatorna végül Aberdeenben épült fel.

Az Egyesült Államok repülőgépgyártói 1940-ben kezdtek el olyan gépeket építeni, amelyek megközelítették a hangsebességet.

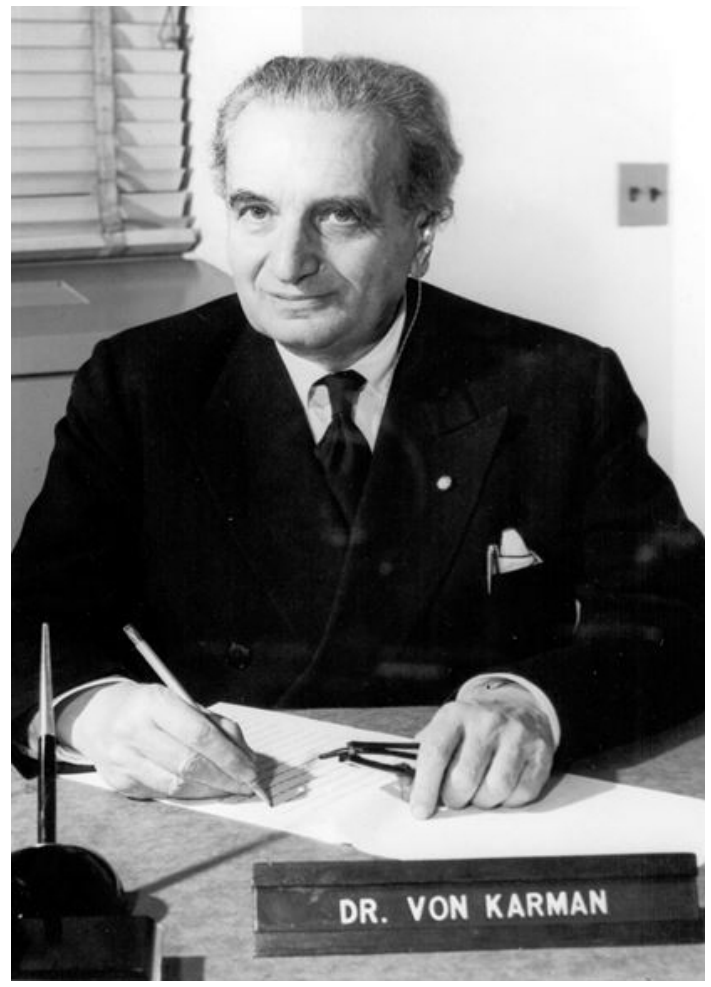

1. ábra. Kármán Tódor az irodájában

\section{Rakétatechnika}

1936-ban három fiatal kereste fel Kármánt, John W. Parsons, Frank Malina és Edward S. Forman, ürrakétát akartak készíteni. A cél egy olyan rakéta készítése volt, amelyet fel tudnak lőni olyan magasságba, ahová már nem tudnak eljutni a léggömbök. 1939-ben megalapították a Guggenheim Aeronautical Laboratory-t a Cal Tech-en, ez volt az Egyesült Államok első rakétakísérlete. A laboratórium 1944-től a Jet Propulsion Laboratory nevet viselte. Ez az az intézmény, ahol Bejczy Antal 1937-től egészen nyugdíjazásáig, 32 éven át tevékenykedett. Az Ercoupe repülőgépet találták a legalkalmasabbnak a rakétakísérletekre. 1941-ben megtörtént az első próbarepülés. A JATO, vagyis a felszállást segítő rakétával felszerelt repülőgép bizonyított, a rakéta csökkentette a felszállás útjának hosszát. 1945-ben közelgett a háború vége. Henry Arnold tábornok azt javasolta, utazzanak Németországba, hogy megnézhessék, mire jutottak a németek a kutatásaikban. Braunschweigtől nem messze az erdőben a katonák addig ismeretlen, titkos laboratóriumra találtak. Kármán és a kutatók csoportja odautazott, hogy szemügyre vegyek az intézményt. Visszatérte után Arnold 


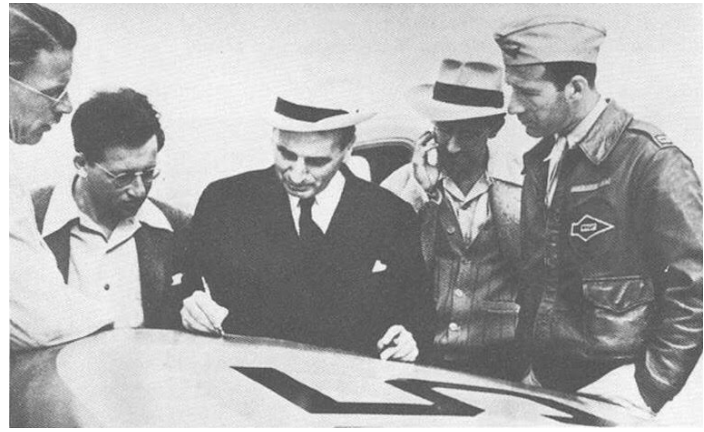

1. ábra. Kármán Tódor számitásokat végez az Ercoupe szárnyán

tábornok felkérte Kármánt, hogy írjon jelentést a Németországban látottakról, a jelentés a Where We Stand címet viselte. Kármán úgy érezte, hogy még nem tud eleget a németek kísérleteiről, ezért újból Európába utazott. Miután minden szükséges információ birtokában voltak, Kármán Tódor közremüködésével napvilágot látott a Towards New Horizons címü tanulmány.1947-ben Stuart Symington vált a US Air Force miniszterévé. Ő támogatta Kármán javaslatát miszerint a légierőnek szükség volna egy új kutatóintézetre, ahol tanulmányozhatják és fejleszthetik a sugárhajtást, a szuperszonikus repülőgépeket és a ballisztikus irányított lövedékeket. Az intézmény, amely az Arnold Engineering Development Center nevet viselte, Tullahomában valósult meg, Harry S. Truman elnök 1952-ben avatta fel. 1953-ban Kármán tódor megalapította tudományos munkaközösségét, melynek elnökévé Neumann Jánost nevezte ki. A közösség tagja volt többek között Teller Ede, Herbert Scoville és George Kistiakowsky.

1950-es években Kármán Tódor már a 70-es éveit taposta, de még mindig aktívan részt vett a tudományos életben, több repülési és űrhajózási társaság tanácsadója volt. 1962-ben az Aerojet éppen 20 éve alakult, ezalkalomból felkérték Kármánt, hogy tartson beszédet.
1962 őszén járt utoljára Budapesten, ekkor avatták a Budapesti Múszaki Egyetem díszdoktorává. Október 22-én az MTESZ-ben előadást tartott és találkozott követőivel. A legfőbb dolog, ami hallgatóságának számára feltűnt, az volt, hogy a hazáját több mint negyven éve elhagyó magyar tudós még aznap is tökéletesen, akcentus nélkül és választékosan beszélte anyanyelvét.

Kármán Tódor 1963. május 7-én hunyt el Aachenben.

\section{Kármán Tódor emléke}

Emlékét őrzik a Holdon $\left(45^{\circ} \mathrm{D}, 175^{\circ} \mathrm{K}\right)$ és a Marson $\left(46,5^{\circ} \mathrm{D}, 59^{\circ} \mathrm{K}\right)$ található kráterek, amelyek az ő nevét viselik, a Budapesti Müszaki Egyetem gépészmérnöki kollégiuma, a róla elnevezett Kármán Tódor-díj, amellyel a felnőttoktatásban és tudományos kutatásokban elért kiemelkedő eredményeket díjazzák. A Magyar Posta 1992-ben bélyeget adott ki az ő emlékére.1989. augusztus 23-án emléktáblát helyeztek el Budapesten, a Szentkirályi utcában, Kármán szülőházán.A Paksi Atomerőmü Rt. elismerésük jeléül 2004-ben mellszobrot állított a részvénytársaság parkjában, amelyet Farkas Pál szobrászművész készített. Ezen kívül a Budapesti Közlekedési Múzeum parkjában is található szobra.

\section{Szakirodalomi hivatkozások}

[1] Lee Edson: Örvények és repülők.

[2] Bödők Zsigmond: Magyar feltalálók a repülés történetében.

[3] Hargittai István: Az öt világformáló marslakó.

[4] Szentesi György: Kármán Tódor és a rakétatechnika. Fizikai szemle 2002/6.

[5] Peter L. Jakab: Kármán Tódor és a modern repülési-ûrkutatási technika kialakulása. Fizikai szemle 1997/3.

[6] Almár Iván: Kármán és az ürhajózás. Fizikai szemle 2002/6.

[7] Szabó Edit: Bejczy Antal - Az ürrobotika atyja. Fizikai szemle 2001/11.

[8] Marx György: A marslakók legendája. 